Studying empirically religious development: Interview, Repertory Grid, and specific Questionnaire Techniques

Author(s): Stefan Huber, K. Helmut Reich and Dominik Schenker

First published: Archiv für Religionspsychologie / Archive for the Psychology of Religion, Vol. 24 (2002), pp. 180-201.

First published by: $\underline{\text { Brill }}$ 


\title{
Studying empirically religious development: Interview, Repertory Grid, and specific Questionnaire Techniques ${ }^{1}$
}

\author{
BY STEFAN HUBER, K. HELMUT REICH, AND DOMINIK SCHENKER
}

\section{Introduction}

Before going into the methodological issues, we state our basic assumptions about human nature and the ensuing conceptualisations in the psychology of religion. The state of the human psyche, human behaviour and related developments are thought to be codetermined by four types of factors (Dennett, 1996, pp. 83-101; Overton, 1999): (1) the biological substrate (body, genetic endowment, central nervous system, - cf. Reich, 2000a); (2) the psychic makeup and its workings (cognition, emotions, conation, etc. but also the unconscious); (3) the proximate and distal human surroundings (significant others, society at large, culture); and (4) the bio-physical environment (climate, geography ...). A complete review of research methodologies and methods would have to go into all four areas. However, the present considerations focus on point (2), with point (3) also getting some attention.

Having delineated the research area, the next question is the status of the research envisaged. In the case of basic research, is the issue at hand (a) beginning in uncharted territory, (b) testing tentative hypotheses, or (c) using and possibly improving on an extant theory? The differences in these three cases as to the best methodology will be illustrated for interview techniques. In case of applied research, methods vary according to whether this is a first-time intervention study with a restricted sample, or a larger scale repeat operation.

Another parameter co-determining the optimum methodological choice has to do with the particular psychological focus: personality, socialisation, development, etc. However, some methods are bifocal, so to speak. Thus, as will be demonstrated shortly, repertory grid techniques, while mainly geared to personality research, can also be used to advance research on development.

As a rule, the psychic makeup and its workings regarding religiosity are considered here from the developmental point of view: How can one elucidate what develops, how that comes about, and what is the result? In this context, psychological constructs play a major role: What is to be investigated, mostly, is not a directly observable attribute, but a psychological "construct", a mental "model" of the phenomenon under study. As the construct cannot be observed directly, the task consists in collecting appropriate data which allow it to be tested by way of deduction and/or retroduction (abduction).

\footnotetext{
${ }^{1}$ Panel presentation at the $8^{\text {th }}$ Symposium for Psychologists of Religion, Sigtuna, Sweden, July 28-31, 2000.
} 
As is well known, research methods fall into two broad classes: quantitative and qualitative methods. Sometimes, the respective protagonists claim a superiority of one class over the other. In contrast, the view taken here is that each has its stronger and weaker points: the optimum choice depends on the research aim (as detailed above), and it may well involve a combination of both types (cf. Bucher \& Reich, 1993, pp. 90-92, "Wider ein Methodenmonopol" [Against a methodological monopoly]). In our subsequent accounts, such combinations will be indicated. No overall inclusive methodological review is aimed at here, but simply a report on our personal experience with relevant methods for studying religious development, namely interview techniques (K.H.R.) the repertory grid technique (S.H.), as well as design and use of a specific questionnaire, which uses experience gained from interviewing as input, and combines qualitative and quantitative approaches (D.S.).

\section{Interviews (K. H. Reich)}

\section{$\underline{\text { Introduction }}$}

Interviews fall into two broad classes (cf. Fontana \& Frey, 1994, for an overview):

(1) free (narrative) interviews, used (in pure research or in psychotherapy) to bring out idiosyncratic features and the corresponding individual development;

(2) problem-oriented interviews, designed to assess respondents' specific competencies and their level of development. The present discussion concentrates on problem-oriented interviews for three types of situations (cf. Reich, 1999, for an extended version): (a) starting a new research, (b) testing tentative hypotheses, (c) situating a person's developmental stage of "religious competence" within an established developmental theory. Before presenting examples of types (a) to (c), a word needs to be said on the technique of carrying out problem-oriented interviews. Basically, it is an impossible task: one wants to let the interviewee speak completely freely so as to know him or her genuinely, in unadulterated from, yet the research aim requires giving a minimum of direction in order to obtain the needed data. For optimum results, the interview should take place in pleasant surroundings familiar to the interviewee. The interviewer should listen in an encouraging, positive manner; depending on the context his or her questions should be wide open (to get started) or narrowly focused (to clarify ambiguous or hedged statements), and the interview should be terminated before fatigue sets in. As Piaget (1926, Introduction) was already aware, interviewees (in particular children) may answer in all sorts of ways not desired by the interviewer such as (i) saying anything which comes to mind to get the interview over, (ii) fantasising, (iii) answering with what is sensed to please the interviewer, (iv) giving an 'inauthentic' answer (provoked by the interviewer' s suggestions and/or 'pressure', or simply repeating what someone else said or wrote). What is wanted are obviously (v) answers which translate the inter- 
viewee's own knowledge, judgement, and relevant competence - a task which calls for a sensitive, experienced interviewer (Reich, 2000b). He or she may need to insist in a friendly yet determined manner without upsetting the interviewee, and to have patience. Sometimes, when one has almost given up hope of obtaining an authentic answer, there at last comes a revolutionary statement which clarifies the situation and sheds new light on the question and the interviewee!

\section{Starting New Research}

In our 10-year longitudinal study on religious and nonreligious world views (Fetz, Reich, \& Valentin, 1989, 2001; Fetz \& Reich, 1989 - see below), we found in a first interview that, as a rule, children's and adolescents' religious world views evolved in a fairly systematic manner: from a world made entirely by an anthropomorphic God working like an artisan (artificialism), to a world made partly by God, partly by nature, and partly by humans, to a world essentially selforganised yet somehow inspired and supported by God seen as force, light, love, the good or the like. Our related research question was: how do these changes come about, what triggers them?

We used a critical incident technique to interview participants about these conceptual developments. Our preparation was as follows: after the second world view interview (between 3 to 5 years after the first interview, using exactly the same questions), we compared and analysed individually the responses from the first and the second interview and noted any content differences in the answers. Then, in the new interview we are discussing, we confronted each interviewee with or his or her differences, and inquired as to why the answer was now different. Next, these interview transcripts were analysed according to the grounded theory procedure (Strauss, 1987; Strauss \& Corbin, 1990). Eight explanatory categories (and one rest category) resulted. The conclusion was that the evolvement of more adequate world views was triggered both by (a) acquiring more and/or categorically different knowledge and (b) recognising the knower in the known, that is, by a more adequate epistemic competence. Details of the interaction between (a) and (b) are discussed elsewhere (Reich, Oser, \& Valentin, 1994; Reich, in press).

To sum up: open questions were used about a clearly circumscribed issue - this without much anticipation of what to expect as answers, let alone formulating definite hypotheses. In this manner, a rich data harvest was obtained which could then be analysed and turned into new insights. Quantitative statistical methods were used to test the significance of the results.

\section{Testing Tentative Hypotheses}

The example in this category is the world view study already referred to (Fetz, Reich, \& Valentin, 1989, 2001; Fetz \& Reich, 1989). As we know from the history 
of ideas in general, and religious studies in particular, (religious) world views have evolved in the course of human history. Also, there are some indications that there exist certain parallelisms between these changes and the changes in the world views of children and adolescents as they grow up (e.g., Reich, 1997). Therefore, the hypotheses were based on the idea that children socialised in religious surroundings would start with a world view fundamentally not contradicting the biblical Genesis (or Plato's Timaeus), but would at some point abandon the notion of a supreme artificialistic maker of all there is.

Taking the cue also from Aristotle's related ideas, an interview guide with 28 questions was designed. These concern the origin of the universe, the detailed way it came about, and its evolution, The semi-structured individual interviews, ini tially with 60 respondents aged 5-19 years, lasted about one hour.

The interview design was further co-determined by the following consideration. As no guiding data were available and the world views of the participants were not known in advance, we had to ensure that the interview guide did not force them into a direction which did not correspond to their own views. Consequently, not just one but four guides were designed, each with 28 questions. Each guide was optimised for one of the following four potential views of the interviewee: (A) Gad has made the world, and it had a beginning; (B) the world came into being on its own, and it had a beginning; (C) Gad has made the world, yet it has always existed; (D) the world came into being on its own, yet it has always existed. The first questions and their answers made it possible to decide whether A, B, C, or D was the interviewee's view, and to continue with the corresponding interview guide. This procedure was well worth the effort: we received plenty of authentic, original answers. Even young children responded only rarely with "I don't know" (less than $2 \%$ of the approximately 100 answers to the standard questions and the requests for clarification).

To sum up: selectively used sets of standardised questions, designed to test the hypotheses under study, yielded a rich relevant material. It was analysed and processed by statistical methods in appropriate cases in order to decide whether the data supported the hypotheses or not. (Most hypotheses were indeed supported.) Furthermore, thanks to a certain flexibility during the interview, unsuspected views were discovered and consequently theory construction was further improved.

\section{Situating a Person's Developmental Stage of Religious Competence within an Established Developmental Theory}

The best known examples under this rubric are, of course, interviews based on Fowler's theory (Fowler, 1981/1995) or on Oser's \& Gmünder's theory (Oser \& Gmünder, 1991; Oser \& Reich, 1996). Assessing the stage of faith development (Fowler) or religious judgement (Oser \& Gmünder) can be construed as a measuring process: an unknown 'quantity' is compared to a standard. In physical measurements, such as those of linear geometrical dimensions or time duration, highly 
accurate comparison standards exist. How about standards of faith stages or stages of religious judgement? Given the complexity of these constructs, one specialised standard per stage is required rather than a single unit standard for all stages. (We are nor dealing with interval scales). These complex stage-dependent standards take the form of a scoring manual: for each stage, a detailed description and a number of standard interview answers are provided, with which the interviewee's actual answers are compared. Consonance between the two translates as identification of the interviewee's stage. During the interview, the interviewee's cognitive structure is explored by questioning his or her initial answers; this exploration proceeds from the perspective of a more developed stage of religious judgement (more developed according to the theory and the scoring manual).

Rather than going into either of these well documented interviews, I discuss the increase in the understanding of Christian doctrines as a function of developing relational and contextual reasoning (RCR - formerly called "Thinking in terms of complementarity" -, Reich, in press).

The basic idea is as follows. The doctrines in question are (1) the Chalcedonian Definition of the two natures of Christ and (2) that of the Trinitarian God (one Godhead yet three personae, God the Father, God the Son, and God the Holy Spirit). Clearly, both doctrines go against the grain of formal binary logic (which is notably involved in Piagetian formal operations). In a prior analysis (Reich, 1990, 1991), I had shown that a trivalent logic, which involves context dependence, is more germane to an understanding of the doctrines. Such a logic is involved in RCR. The assumption was therefore that persons who clearly understood the doctrines we are discussing would also solve appropriate problems at high RCR levels.

The interview therefore consisted of two parts (Reich, 1994). The first part was a fairly open interview about the following two texts:

(1) The Fathers who met in 451 at the Council of Chalcedon declared notably that "Our Lord Jesus Christ is truly God and truly man ... made known in two natures [which exist] without confusion, without change, without division, without separation." What do you think about this Chalcedonian Definition?

(2) Christian theology teaches the Doctrine of the Holy Trinity: The Father, the Son, the Holy Spirit. What is your opinion about this doctrine?

Twenty-six persons participated in both partial interviews (1) and (2) and four additional persons each in only one of them.

The interview transcripts were analysed and ordered into three classes: (1) "The doctrines are rationally incomprehensible, one can only believe them"; (2) "The doctrines are really strange, but I understand something; (3) "I understand the doctrines fully - they express well what I believe" (justifications provided).

In part 2 of the interview the three standard problems used for assessing the respondent's RCR level (Reich, in press, chapter 4) were administered to all 30 participants. (Respondents are asked for a decision on whether an artistic performance is due to genetic endowment or to practice, whether an accident in a nuclear power plant is due to a technical malfunctioning or to human failure, and whether the behaviour of human beings is 'governed' by the body or by the mind /the 
heart). The interview transcripts were rated according to the RCR coding manual. The results are shown in Table 1 and Table 2.

Table 1: Frequencies of individual scores for levels of relational and contextual reasoning, RCR, and intelligibility judgement of the Chalcedonian Definition

\begin{tabular}{ccccc}
\hline NP & Level of RCR & $\begin{array}{c}\text { Is the Chalcedonian } \\
\text { Group 1 ("no") }\end{array}$ & $\begin{array}{c}\text { Definition rationally } \\
\text { Gr. } 2 \text { ("partly") }\end{array}$ & $\begin{array}{c}\text { Group 3 ("yes") } \\
\text { III(IV) }\end{array}$ \\
1 & IV(III) & & & \\
8 & IV & 2 & 6 & 4 \\
12 & IV(V) & 4 & 4 & 8 \\
6 & V(IV) & & 11 & 8 \\
28 & & 9 & & 4 \\
\hline
\end{tabular}

Level III(IV) is somewhat above level III; $\mathrm{N}(\mathrm{III})$ is somewhat below $N$, etc. $\mathrm{N}_{\text {tot }}=28$; mean age 33 years, 8.4 months; SD 15 years, 2.3 months. Source: Reich (1994,p. 121).

Table 2: Frequencies of individual scores for levels of relational and contextual reasoning (RCR), and intelligibility judgement for the doctrine of the Holy Trinity

\begin{tabular}{|c|c|c|c|c|}
\hline \multirow[t]{2}{*}{$\mathrm{NP}$} & \multirow[t]{2}{*}{ Level of RCR } & \multicolumn{3}{|c|}{ Is the Doctrine of the Trinity rationally understandable? } \\
\hline & & Group 1 ("no") & Gr. 2 ("partly") & Group 3 ("yes") \\
\hline \multirow{3}{*}{2} & III & & & \\
\hline & III(IV) & 2 & & \\
\hline & IV(III) & & & \\
\hline 8 & $I V$ & 3 & 5 & \\
\hline 12 & $\mathrm{IV}(\mathrm{V})$ & 1 & 6 & 5 \\
\hline 4 & $\mathrm{~V}(\mathrm{IV})$ & & & 3 \\
\hline 28 & & 9 & 11 & 8 \\
\hline
\end{tabular}

$\mathrm{N}_{\text {tot }}=28$; mean age 32 years, 0.3 months; SD 15 years, 4.9 months. Source: Reich (1994).

The data of both tables share the same features: All participants who responded below level IV of relational and contextual reasoning belong to group 1. (This statement is not reversible, however; in group 1 there were also respondents who were capable of higher level reasoning, yet they lacked religious knowledge or in- 
terests). Participants in group 2 reasoned at least at level IY, those of group 3 at least at level IV (V), which is somewhat above level IY.

Kendall's rank correlation coefficient has significant values, $\mathrm{r}_{\mathrm{K}}=.40, \mathrm{p}<.02$ for the values of Table 1 , and $\mathrm{r}_{\mathrm{K}}=.56, \mathrm{p}=.001$ for those of Table 2 . These correlations are further supported by $\mathrm{H}$ tests (Kruskal and Wallis - one-way analysis of variance of ranks) and U tests (MannWhitney -composite-rank test for samples of unequal size). To sum up: fairly open interviews about two Christian doctrines led to a classification of the participants into three groups with, respectively, no, some and full understanding of the doctrines. Standard structured interviews were used to assess participants' level of RCR. By relating both (formally independent) results to each other, it was established that a high level of RCR is a necessary condition for rational understanding of the doctrines concerned. Hence, understanding seems to develop along with the development of an appropriate form of reasoning. Statistical computations confirmed the significance of the results.

\section{Religious Development Mirrored by the Repertory Grid Technique (S. Huber?}

The Repertory Grid Technique (RGT) is an empirical method designed to study idiosyncratic psychological characteristics, including individual religious development. After a brief exposition of the underlying principle, the specifics of the related interview procedure and the ensuing data treatment, two model cases serve to demonstrate the reconstruction of the interviewee's religious development.

\section{The Repertory Grid Technique}

The RGT was developed by George Kelly in the 1950s within the framework of Persona! Construct. Psychology, PCP (Kelly, 1955; http://repgrid.com/pcp, from which this paragraph is partly drawn). Kelly was a clinical psychologist and educator, and the primary impact of his work, initially, was in psychotherapy and education. In his view, a person's experiencing and acting is co-determined by the way that person views other persons, the biophysical surroundings, and himself/herself. Kelly (1955) saw people as driven by the need to cope with coming events in the world and all other aspects of behaviour as deriving from this need: "A person's processes, psychologically speaking, slip into the grooves which are cut out by the mechanisms he [/she] adopts for realising his [/her] objectives" (ibid., p. 49). Kelly devised a method for rendering visible an individual's personal patterns of perceiving and acting so as to know what to correct and to develop. He labelled the basic axioms involved in PCP "elements" (the 'objects' / 'incidents' to be gauged) and "constructs" (the attributes of the elements). A construct is a basis for making a distinction, a dichotomous reference characteristic. Thus, each reference represents not a line or continuum, as in analytic geometry, but one, and only one, distinction (bipolar characteristics). Ac- 
cording to Kelly, constructs are used for predictions, and can be revised if proven wrong (ibid., p. 14).

The interviews are based on (a) working with suitable elements sensu Kelly (proposed either by the interviewer or the participants, or both), and (b) letting each participant indicate his or her personal bipolar constructs. If religiosity is the abject of study, then persons - religious or not - are suitable elements. The bipolar character of the constructs means that only a combination really fixes their sense. Take "catholic": opposed to "Protestant" it signifies Roman Catholic, opposed to "denominational" it means universal, and opposed to "liberal" it means doctrinal.

According to what has been said so far, the RG interview is not very different from the usual structured interview that aims at elucidating how the interviewee construes/solves the issue at hand. However, the RG interview involves a further step.

Once participants have indicated their constructs, they are invited to apply them systematically to all elements, i.e. here to all persons functioning as elements. The task is to decide which of the construct pales applies, and to what degree. For instance, Mother Theresa would be helping others - not selfish - and this to the highest degree. This procedure resembles that of the semantic differential. The difference is that in the RG case, participants work with their own dichotomous attributes. The overall result is an idiosyncratic net of quantitative relationships between the elements and the constructs, which expresses the particular views of a given participant. The data treatment starts from the net just referred to, structured as a Kelly matrix with the numerical values of the constructs as rows and the elements as columns. The aim of the data treatment is the best possible presentation of the differences and communalities between elements and constructs. This is achieved by a dual principle components analysis, which is based on a singular values decomposition (Young \& Householder, 1938) ${ }^{2}$. Using this method, a "biplot" (Gabriel, 1971; Gower \& Hand, 1996) can be computed, in which persons and constructs are presented as vectors in a single co-ordinate system. Such a biplot - occasionally referred to as a cognitive map - represents a idiographic model of a respondent's subjective views. The rules for its interpretation will be explained shortly.

\section{A First Case Study of Religious Development}

The two cases are taken from a study made in 1998 with 17 students and three older adults (cf. Huber, 1999, 2000b, 2000c, 2000d). This study aimed at elucidat-

\footnotetext{
2 The real rectangular Kelly matrix $\mathrm{X}$ is decomposed into the right eigenvector matrix $\mathrm{U}$, the diagonal matrix $\mathrm{L}$ of singular values, and the right eigenvector matrix A. Both $\mathrm{U}$ and $\mathrm{A}$ are de- fined as column orthogonal ; the basic relation being $\mathrm{X}=\mathrm{ULA}^{\prime}$. $\mathrm{U}$ and $\mathrm{A}$ are rotation matrices, which rotate an assembly of points from the old location to the new location, namely $\mathrm{U}$ the elements in the coordinate system of the constructs, and A the constructs in the coordinate system of the elements. The statistics were worked out by Slater $(1964,1976,1977)$. As to the details of the ensuing various possibilities for the presentation of results, the reader is referred to the exposition by Raeithel $(1993,1995)$.
} 
ing the participants' religious assessment of 20 well-known religious personalities, and of themselves in the past, the present, and the future ${ }^{3}$. I refer to the first selected individual as Paul; he then was a theology student, aged 27 years.

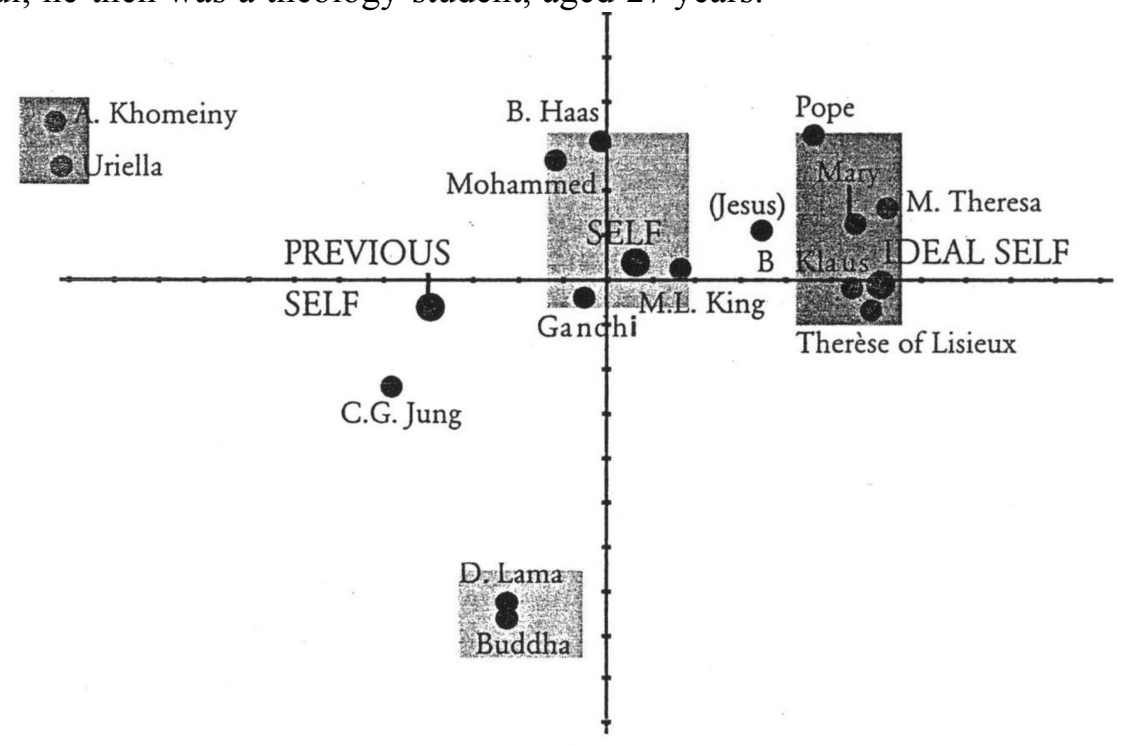

Fig. 1: Paul's view of religious personalities (without constructs)

The simplified Fig. 1 only shows Paul's perception of 15 personalities and him- self, not their attributes. To show immediately the attributes, too, would make the figure harder to understand. Two rules govern the interpretation:

- The more unambiguous Paul's assessment, the further from the origin of the co- ordinate system that religious person is located.

- The more similar Paul judges two personalities, the smaller is the distance be- tween their respective locations.

Jesus is a special case. Paul had difficulties in determining himself in relation to Jesus, because he perceived Jesus as basically different from all other persons. The result was that the evolved system of constructs did not fit Jesus - his location is not specifiable - and therefore his name is placed in parentheses.

If one analyses the location of the other 14 religious personalities and Paul, one can distinguish several groups, colour-coded ${ }^{4}$ according to Paul's valuations (indicated as a rule, by their position with respect to the first principal axis [x-axis]):

\footnotetext{
${ }^{3}$ This study built on earlier work, in which possibilities for studies of individual views on re- ligiosity were examined (Huber, 1996, 1998, 2000a).

${ }^{4}$ Unfortunately, the coloured figures can here only be reproduced in black and white.
} 
- the 'green' group (on the right side), Therèse of Lisieux, Brother Klaus, Mary (mother of Jesus), Mother Theresa, and the Pope, includes Paul as he ideally sees himself The location of the ideal self within the green group indicates its positive valuation;

- two 'red'groups (on the left side):

- the 'extreme' red group, Ayatollah Khomeiny and Uriella (a female guru), is located the furthest away from the green group, indicating a negative valuation;

- the 'moderate' red group, C. G. Jung and Paul's previous self are also viewed negatively, but far less so than the 'extreme' red group;

- two yellow' groups, which comprise personalities valued as 'neutral':

- the group in the centre, Gandhi, Martin Luther King, Mohammed, Bishop Haas, and Paul's current self, is the most clearly valued as 'neutral';

- the lower group, the Dalai Lama and the Buddha, is valued as neutral in regard to the right-left location, but clearly separated from the other groups as to the up-down location (the second axis).

The next interpretative step additionally involves Paul's constructs (Fig. 2). That 'mode!' of Paul's assessments explains 720/o of the variance of his data matrix, that is it represents that assessment quite well. I have again edited the figure by adding 'colour' in order to bring out the central constructs and their value- judging character:

- The "centrality" of a construct is indicated by the length of its vector. The further the endpoint is from the origin of the coordinate system, the better Paul was able to discriminate between the characteristics of the various personalities, the more central that construct is in his assessment system. The most central constructs are indicated by fat grey dots, the others by small white dots.

- The valuation of a construct translates as its right-left location: 'green' positively on the right (Paul's ideal), 'red' negatively on the anti-ideal locations. The neutrally valued constructs (yellow) are demarcated from each other via their up- down location.

Now to the detailed interpretation, the valuations first: The four 'green' constructs (on the right side) signify that the person referred to is (i) dedicated to God, (ii) God's channel, (iii) accepting, and (iv) helping others. The contrasting poles are (i') self-initiating, (ii') highhanded, (iii') defensive, (iv) selfish. These constructs show that Paul's perception of religious persons is determined by an opposition between God and human egocentricity.

His ideal of a religious person includes an ethical and an aesthetic component. The ethics is characterised by care for others and building a community. The pertinent constructs are helping, taking responsibility, peaceable. The aesthetics is based 


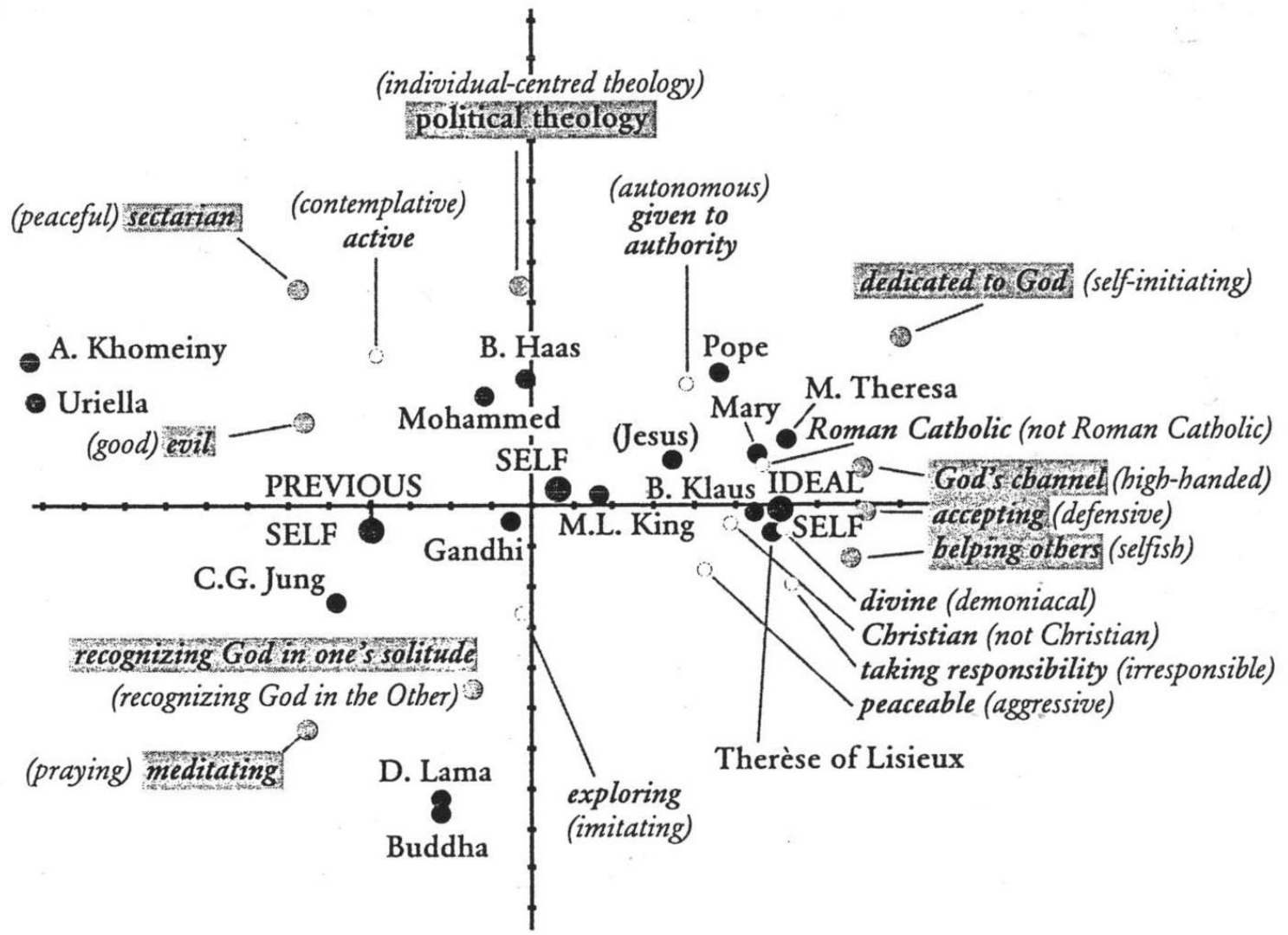

Fig. 2: Paul's view of religious personalities (with constructs)

on a conceptualisation of the world as face to face with a personal God. The corresponding constructs are dedicated to God and being God's channel.

Consonant with his aesthetics, Paul constructs an opposition between meditating and praying. Praying constitutes the positive pole, obviously because it relates to God 'face to face'. In contrast, Paul values meditating negatively, presumably be- cause he construes it primarily as a self-centred practice of religious devotion.

And now to the constructs differentiated by their up-down location: these constructs express, above all, Paul's distinctions between the functions of religion with reference to society and those regarding individuals. The contrasted, pertinent categories are political theology and recognising God in one's solitude. The ideal religious- ness is located halfway between both functions. My interpretation is that, for Paul, both are equally important; he would judge negatively an exclusive emphasis on only one of them.

Finally, we come to Paul's religious development. It can be summarised as follows:

1. Paul judges his current self as neither positive nor negative - we may say that he is in a transition phase.

2. The distance between the previous self and the current self indicates Paul's actual development, and the distance between the current self and the ideal self shows the developmental potential. 
3. Contentwise, Paul's religious development is co-determined by his perspective of individual 'sanctification', characterised by his perceived opposition be- tween his dedication to a persona! God and self-seeking tendencies of his ego.

\section{$\underline{\text { Second Case Study }}$}

As we have seen from his biplot (Fig. 2), Paul lives in a world of traditional Christian devotion. Peter, a Catholic religious educator (age 53), presents a contrasting case in that his view of religiosity is shaped by liberation theology. He named Oscar Romero, Pedro Arupe, and a fictive member of the Opus Dei as additional religious personalities of particular (positive/negative) importance to him. Romero, Arch- bishop of San Salvador from 1977, was shot dead on z4th March 1980 while per- forming mass. The Very Rev. Pedro Arupe, superior general of the Society of Jesus, was an outspoken Jesu it known for his social justice outlook. The Opus Dei ("God's Work") is a conservative ('rightist') Roman Catholic organisation of laymen and priests whose members pledge to seek persona! Christian perfection and strive to implement Christian ideals in their chosen occupations. Already, these additions indicate that, for Peter, the political function of religion ranks high. Peter used 13 bipolar constructs of his choice to characterise the various religious persons.

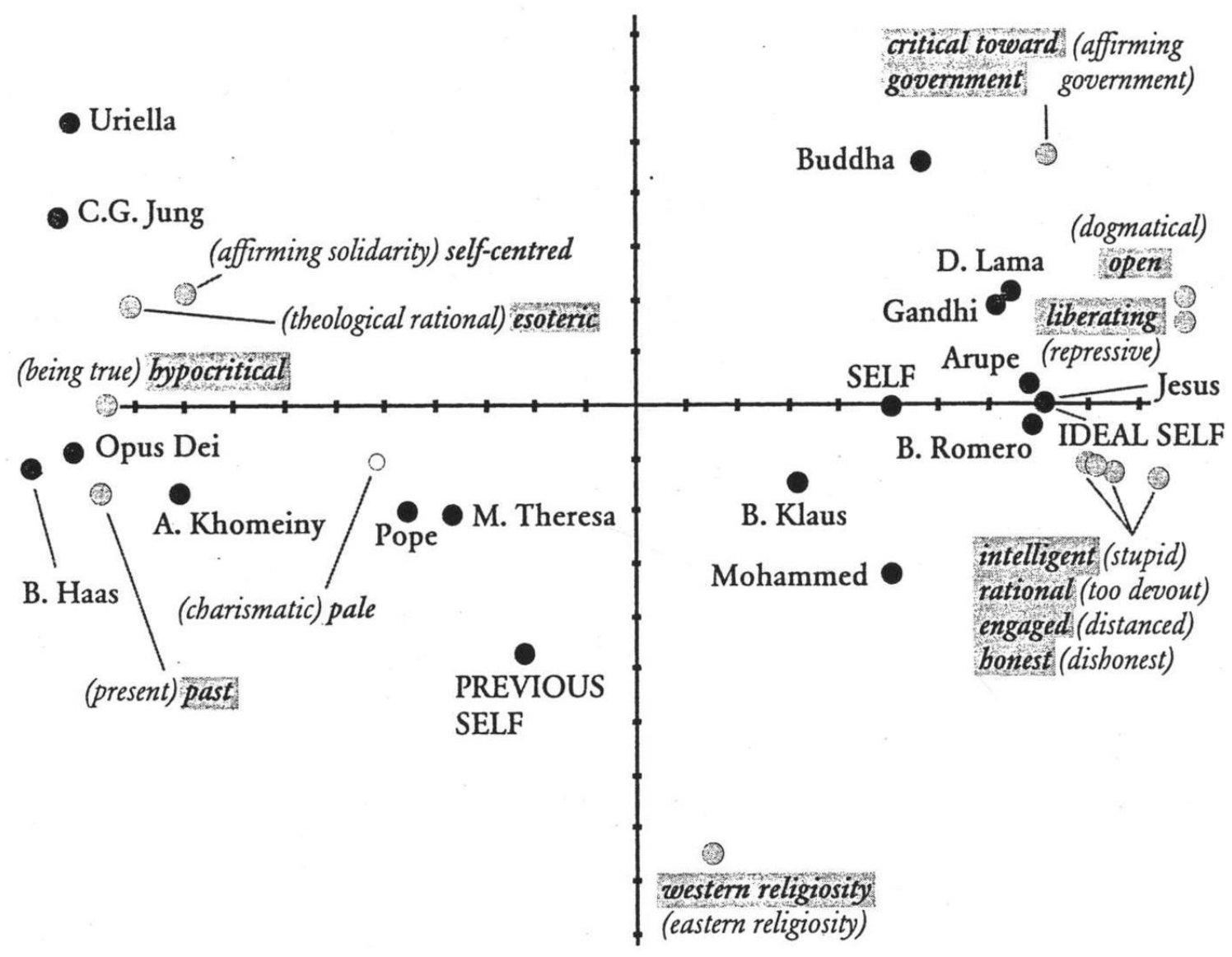

Fig. 3: Peter's view of religious persons 
Peter's biplot (Fig. 3) demonstrates a strong polarisation of his perception. Barring a few exceptions, the religious persons are classed either as very positive, or as very negative. The 'neutral' centre rests empty. His ideal self is fused with Jesus; B. Romero and Arupe are quite close. Clearly, Buddha, the Dalai Lama, Gandhi, his current self, and Mohammed are all perceived positively. Uriella (a female Guru), C.G. Jung, Opus Dei, B. Haas and A. Khomeiny constitute the contrasting negative pole. As a tendency, Peter also perceives the Pope and Mother Theresa negatively. Excepting "western religiosity" / "eastern religiosity", all constructs load highly on the first main axis (the x-axis), and only modestly on the second main axis (the y-axis). In view of this, Peter's system of constructs can be characterised as (nearly) one-dimensional.

He describes his ideal religious self as critical towards government, open, and liberating as well as intelligent, engaged, honest and rational. The corresponding contrasts are: affirming government, dogmatical, and repressive as well as stupid [sic], distanced, dishonest, and too devout. This state of affairs mirrors Peter's liberation theology position, which is determined by the opposition between repression and liberation. That position implies Peter's acceptance of both rationality (intelligent, engaged, theologically rational) and moral integrity (honest, affirming solidarity, and being true). When religion is viewed from such a perspective, its political function is central. One can surmise that, according to Peter, political engagement is the most important kind of religious activity. By comparison, other kinds such as prayer and church service take a back seat. At least, they do not surface in his assessment of religious personalities.

Peter's development shows in the biplot as follows (Fig. 3):

1. Peter values his current self clearly as positive. Unlike Paul, Peter does not find himself in a transition phase but in an established position. This interpretation is supported by the relative closeness of the current self to the ideal self.

2. In contrast, a large distance separates the current self from the previous self, the distance extends from the negative side of the first principle axis to the positive side. This indicates that Peter recognises a marked break in his religious development.

3. Contentwise, that break can be interpreted as a change from a rather conservative theological position to a position based on liberation theology. As regards the constructs intelligent, rational, engaged, and honest, Peter sees a near-continuity from his previous self and his current self ${ }^{5}$. In contrast, his previous self and

\footnotetext{
${ }^{5}$ To assess the valuation of a given person with reference to a particular construct, one draws a line through the person's location at a right angle to a line connecting the construct location with the origin of the coordinate system. The further the intersection of the two lines from the origin, the stronger the construct applies to that person. As the contrasting pole is located on the mirror side, the valuation changes sign as the origin is crossed. When looking at Fig. 3, the previous self seems to be valued negatively with respect to intelligent, rational engaged, and honest. However, according to the data matrix, it is valued slightly positively. This discrepancy can be ascribed to the error of the biplot (the variance is explained to $89 \%$ only). To be on the safe side, it is always recommended to compare the biplot with the Kelly matrix; this in particular, when developmental changes exhibit large divergencies in their evaluation.
} 
the present self differ sharply in terms of their up-down location: affirming government has become critical toward government, dogmatic has turned into open, and the former repressive is now liberating.

\section{Outlook for the Future of Using RGT}

Paul's religious views provide one example of a typical Christian religious devotion. But Peter represents clearly a different case. Among other things, Peter's cur- rent self is located much closer to the ideal self. The ideal self is further out to the right than that of Paul, and Jesus is located close by. The theological categories constitute a second difference between Paul and Peter. Paul represents a traditional form of Christian piety and Peter liberation theology. That there are marked differences between the individual views of the 20 participants was confirmed by a quantitative comparison (Huber, in preparation). Hence, the RGT can render valuable research assistance and should be used more often in the future (cf. Hass, 1974; O'Connor, 1983; Todd, 1977).

To sum up what the method can furnish: (a) a tool for interpreting idiosyncratic views on religiosity and its development. Pari passu religious contents and their effects come into view (which is not the rule in research on religiosity). (b) Thanks to the possibilities of quantification, interindividual comparisons are possible. RGT therefore constitutes a bridge between qualitative and quantitative methods; the authors hope that it will be used increasingly in future studies of religiosity and religious development.

\section{Input from lnterviewing into Questionnaire Design(D. Schenker)}

\section{Overview}

The specific questionnaire technique we are discussing will be demonstrated by way of researching the question "Why do persons think on certain occasions that God punishes them?" Theoretical explanations of any reason(s) for such a consideration are rare; this with the exception of some cognitive developmental theories. Unfortunately, these theories stand isolated from the mainstream of contemporary psychology of religion; they are not integrated. There are several reasons for this. Maybe a first reason is that there presently exists no confirmed model of religiosity that combines developmental and mainstream approaches. The heuristic model of religiosity presented here attempts to solve that difficulty; it connects the structure-genetic cognitive approach with an approach based on personality psychology (for another attempt, see Reich, 2000). After presentation, it is applied to an empirical study of a God perceived as rewarding and punishing.

A second reason for the indicated state of affairs could be that the two approaches to elucidating an individual's religiosity usually involve different re- 
search methods (interviews vs. questionnaires). Semi-open interviews enable one to study, by retroduction, the development of religious cognitive structures under various conditions (see above). In contrast, closed questions, used in questionnaires for ease of data treatment, are more suited for elucidating personality traits that co-determine a person's religiosity. One main objective here is to show how the experience gained from interviewing can be fed into the design of a questionnaire of a specific type in such a way that the advantages of bath research methods are combined.

\section{Three Basic Aspects of Religiosity. A Heuristic Model}

Introduction. As mentioned previously, cognitive, structure-genetic approaches to the psychology of religion and trait-oriented approaches have confronted each other so far without much 'dialogue' (cf. Bucher \& Oser, 1987). A basic assumption of the theory of religious development is that an individual, as a cognitively active being, searches for, and co-constructs a sense of his or her life, partly in dialogue with the surrounding beings (cf. Oser $\&$ Reich, 1992, p. 67). The development of this religious meaning-making manifests itself as a series of developmental stages which differ qualitatively: the stages of religious judgement. (Oser \& Gmünder, 1991; Oser \& Reich, 1996). The mental structure corresponding to these stages constitutes a "cognitive frame"; gaining religious knowledge and interpreting the world occurs within that frame.

In contrast, protagonists of an approach inspired by personality psychology consider that a person's religiosity involves fairly stable features (traits), that is, individually distinct dispositions, attitudes, habits, and behaviours.

As regards empirical findings, the following three facts are established:

1. Qualitatively different thought patterns corresponding to the stages of religious judgement (Oser \& Gmünder, 1991) are confirmed.

2. Factor-analytical studies demonstrate several distinctive dimensions of religiosity. Most of them share a strong first factor, often referred to as "general religiosity".

3. Nevertheless, most religious items in questionnaires and related scales correlate comparatively strongly by comparison with nonreligious items, which could be interpreted - in contrast to point 2 - as religiosity being unidimensional, or that a second factor may be operative.

The heuristic model presented here is built upon these three findings: the model attempts to bind together the structure-genetic and trait-oriented approaches. Oser and Gmünder's Stages of Religious judgement. This is the first aspect of the model we are discussing. According to Oser and Gmünder (1991, p. 139-140), "The most fondamental presupposition and basis for any (religious) knowing is represented by the structures of religious cognition. They form the basic 
conditions of religious learning and meaning-making. Each stage constitutes the shaping context within which knowledge and content are assimilated and processed".

The Multidimensionality of Religiosity. This is the second aspect of the model. A series of empirical investigations have established the multidimensionality of re- ligiosity in terms of personality characteristics (traits). The corresponding factor- analytic studies yield evidence for several independent dimensions of religiosity (e.g. Huber, 1996, pp. 108-161).

The Depth and Strength of Religiosity, or its Persona/ Meaning. As already indicated, items in questionnaires and related scales correlate comparatively strongly by comparison with nonreligious items - the third aspect of the model. This corresponds to the every-day experience that persons considered religious nevertheless differ regarding their valuation of religion, its meaning, and the depth and strength of their religiosity. $\ln$ other words, one can assume that a second factor obtains in religiosity, which expresses interindividual differences within a broadly comparable religiosity.

As regards methodology, assessing the stages of religious judgement calls for semi-open interviews, whereas the multidimensionality of religiosity and its depth and strength can be studied via closed questions. As the difference is not always appreciated, a small digression is in order. We ail have an active vocabulary (which we use spontanously), and a passive vocabulary (words we 'under- stand' but would not use spontaneously, for instance because we are not quite sure of their meaning). Similarly, we can understand arguments (of a religious, moral, or similar nature) enunciated at a 'higher' developmental stage than our own, but we could not have formulated them. Therefore, presenting multiple choice questions pertaining to different developmental stages will not bring out with precision the actual developmental level reached. That can only be achieved via appropriate interviews about dilemmas (which, for a larger sample, can be completed in written form). To illustrate this statement by way of an example: If one wants to know whether an interviewee is aware of how Columbus made an egg stand upright, would it be reasonable to ask something like, "Did he balance an egg on its end, or did he set it clown so hard that it was slightly damaged in such a way that it stood upright?" Obviously, a person not knowing beforehand how Columbus did it, would immediately understand that the second part of the question contains the correct answer, and so respond: such a method would be self-defeating.

In the following example, 1 concentrate on the above first two aspects of religiosity (developmental stages and multidimensionality).

\section{An Empirical Study of a GodPerceived as Rewarding and Punishing}

Design of the questionnaire. Perceiving God as rewarding and punishing is typical for persons reasoning at stage 2 of religious judgement. That conceptualisation 
here is regarded as a dimension of religiosity, that is, in the model as part of its multidimensionality (second aspect).

The hypothesis is that respondents arguing at stage 2 will accept the perception of Gad as rewarding and punishing to a higher degree that those arguing at stages 3 and 4 .

In the 91 item questionnaire, a shortened version of the Paul dilemma (see Appendix) is used, modified appropriately in that answers have to be justified. The questionnaire is designed specifically for discriminating between stages 1 and 2 on the one band, and stages 3 and 4 on the other hand ${ }^{6}$. The following three additional items (reward and punishment) seize on the perception of a rewarding and punishing Gad (answers on a 4-point Likert scale):

- "When something bad happens, I have sometimes asked myself what reasons God could have for punishing me'

- "God's acting is a directmirror of our acts, that is, Godrewards and punishes us for our deeds".

"Every person receives from God good things and badthings, exactly asmerited".

Results. The results originate from a questionnaire study ${ }^{7}$ involving 362 adolescents and young adults from German-speaking Switzerland, aged 16 to 30 years (Schenker, 1996). From the answers to the Paul dilemma it transpired that 95 per- sans scored at stage 2, 130 at stage 3 , and 61 at stage $4(N 24=286) ; 33$ persons $(10.3$ percent $)$ were self-confessed atheists and were considered separately. A total of 43 persons gave unclear or insufficient information and could not be classified.

The mean values (maximum 4) on the "reward and punishment" scale are for the stage-2 participants $2.4, \mathrm{SD}=.76$; for stage- 3 participants $1.84, \mathrm{SD}=.72$; and 1.5 for stage- 4 respondents, $\mathrm{SD}=.82$. As expected in theory, the respondents scoring at higher stages are significantly older. Furthermore, age correlates negatively $(r=-.41)$ with the "reward and punishment" scale. Therefore, the influence of age was assessed by means of a covariance analysis. The results were highly significant $\left(\mathrm{P}_{\text {stage }} .000 ; \mathrm{P}_{\text {age }} .000\right)$.

In a second step, a modern Chaid program (Answer Tree 1.0) was used to elucidate how the respondents differed according to their answers to all items or scales (94 items in total) (Fig. 4). The "reward and punishment" scale differentiates most clearly between the stage-2, stage- 3 and stage- 4 respondents.

Both the covariance analysis and the answer tree analysis point up a significant relation between the stages of religious judgement and the "reward and punishment" scale. However, there is also (indirect) evidence for other influences besides the stages of religious judgement regarding acceptance of a Gad who rewards and punishes. How else is one to explain that 12 stage- 2 persons did not accept such a Gad, but 5 stage- 4 persons did? It would certainly be interesting to interview those

\footnotetext{
6 When I developed this questionnaire, I was unaware of B. Rollett's (1996, pp. 107-124) version. I now use an extension of Rollett's version, but my own scoring rules.

7 The objective of this study was to elucidate whether young people appreciate religion as a help in coping or not.
} 


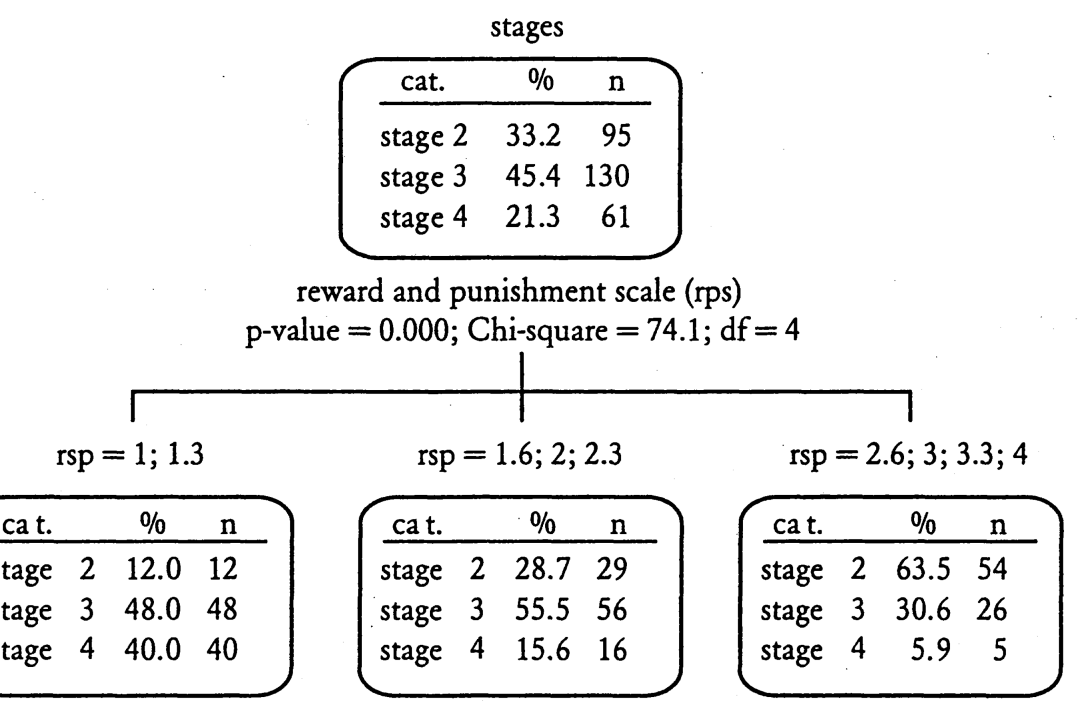

Fig. 4: Top: Distribution of participants' stages of religious judgement (RJ). Below: Distribution according to RJ stage and individual mean scores (groups low, middle, bigh) for the Reward and Punishment Scale (rps - highest score: 4)

persons in order to decide whether the theory of religious judgement or the present methodology needs refinement.

\section{Conclusions}

We have shown by way of a number of examples from our own research on religious development that, on the one hand, there has to be a match between the research aim and the method used, and on the other band, in favourable cases at least two aspects of the question researched can be elucidated by a combination of methods, or even by an appropriate single method.

Acknowledgements. We thank the participants of our various empirical studies for their collaboration: without them we would have little to say.

\section{Appendix: Part of the Questionnaire Used by D. Schenker (current version)}

Please read the following story and answer the subsequent questions:

Paul is a young physician. He plans to marry his fiancée in the near future. Before taking up an outstanding position in a private clinic, he makes a journey by air. Shortly after take- off, the plane's captain announces that one engine is malfunctioning and that the other is functioning unreliably. The plane is losing altitude. The plane races toward the ground at 
great speed. Paul's entire life flashes past his eyes. He knows it's ail over. In this situation, be remembers God and begins to pray. He promises that, if be is somehow saved, be will dedicate his life to helping people in the Third World. The plane crashes in a field - yet, by a miracle, Paul survives!

Paul does not know what be should do now. Should be get married and work in the private clinic or go to the Third World, knowing that his fiancée does not want to go there under any circumstances?

Should Paul keep his promise made to God? $\quad \square$ Yes $\square$ No

Please justify your answer:

According to you, what is more important?

$\square$ The good position in the private clinic and his fiancée or

$\square$ The promise made to God?

Please justify your answer:

If you were Paul, what would you do?

Please justify your answer:

Imagine that Paul does not go to Africa. He marries his fiancée and accepts the offer of the private clinic. Soon afterwards, be suffers a grave care accident. Has that any- thing to do with the broken promise?

Please justify your answer: 
Bucher, Anton A. \& Oser, Fritz (1987) Hauptströmungen in der Religionspsychologie. In: D. Frey, C. Graf Hoyos \& D. Stahlberg D. \{Eds), Angewandte Psychologie \{pp.466-486\}. München/ Weinheim: Psychologie-Verlags-Union.

Bucher, Anton A., \& Reich, K Helmut. (1993). Gottesverständnis und religiöse Urteilsbildung. Ein stufentheoretischer Zugang nach Oser/Gmünder. In: Comenius-Institut (Ed.), Religion in der Lebensgeschichte -lnterpretative Zugänge am Beispiel der Margret E. \{pp.68-92). Gütersloh: Gütersloher Verlaghaus.

Dennett, Daniel C.(1996). Kinds ofminds. Toward an understanding of consciousness. New York: Basic Books.

Fetz, Reto L., \& Reich, K Helmut (1989). World views and religious development. Journal of Empirical Theology, 2 (2), 46-61.

Fetz, Reto Luzius, Reich, Karl Helmut, \& Valentin, Peter (1989). "Cosmogony" according to children and adolescents: An empirical study of developmental steps. In: J. M. van der Lans \&J.A. van Belzen (Eds), Proceedings of the Fourth Symposium on the Psychology ofReligion in Europe \{pp. 51-63). Nijmwegen, the Netherlands: Department of Cultural Psychology and Psychology of Religion of the University of Nijmegen.

Fetz, Reto Luzius, Reich, Karl Helmut, \& Valentin, Peter (2001). Weltbildentwicklung und Schöpfungsverständnis. Eine strukturgenetische Untersuchung bei Kindern, Jugendlichen und jungen Erwachsenen. Stuttgart: Kohlhammer. see p. 246.

Fontana, Andrea, \& Frey, James H. (1994). lnterviewing. The art of science. In: N.K Denzin \& Y.S. Lincoln (Eds), Handbook of qualitative research \{pp.361-376). Thousand Oaks, CA, etc.: Sage.

Fowler, James W. (1981). Stages of faith: The psychology of human development and the quest for meaning. San Francisco: Harper. (PB 1995).

Gabriel, KR. (1971). The biplot-graphic display of matrices with applications to principal components analysis. Biometrika, 58, 453-467.

Gower, J.C., \& Hand, DJ. (1996). Biplots. London: Chapman and Hall.

Hass, L.L. \{1974). Personal construct systems and theological conservatism. Doctoral dissertation, University of Nebraska, USA.

Huber, Stefan \{1996). Dimensionen der Religiosität. Skalen, Messmodelle und Ergebnisse einer empirisch orientierten Religionspsychologie. Bern: H. Huber.

Huber, Stefan (1998, September). Subjektive Sichtweisen der Religiosität. Eine Untersuchung zur kognitiven Repräsentation des christlichen Glaubensbekenntnisses. Paper presented at the "41. Kongress der Deutschen Gesellschaft für Psychologie", Dresden, Germany.

Huber, Stefan (1999, September). Subjektive Sichtweisen der Religiositiit ais individuelk Bedingung religioser Entwicklung. Poster presentation at the "14. Tagung für Entwicklungspsychologie", Fribourg, Switzerland.

Huber, Stefan (2000a). Nonmetrische Multidimensionale Skalierung (NMDS) als Messmodell für subjektive Sichtweisen der Religiosität. ln: Ch. Henning \& E. Nestier (Eds), Religionspsychologie heute \{pp. 361-377). Frankfurt am Main: P. Lang.

Huber, Stefan \{2000b, February). Subjektive Sichtweisen der Religiosität im Spiegel der Repertory Grid Technik, Paper presented at the "9. Konferenz der Deutschen Arbeitsgruppe zur Psychologie der persönlichen Konstrukte (DPPK)", Frankfurt am Main, Germany.

Huber, Stefan (2000c, March). Individuelle Religiosität im Spiegel der Repertory Grid-Technik, Paper presented at the "5. Arbeitstagung Empirische Forschung in Psychotherapie und Seelsorge", Oberursel, Germany.

Huber, Stefan (2000d, March). Individuelle Konstruktion religiöser Personlichkeiten, Paper presented at the "3. Religionspsychologische Fachtagung der katholischen Akademie Rabanus Maurus", WiesbadenNaurod, Germany.

Huber, Stefan \{ln preparation). Individuelle Religiosität im Spiegel der Repertory Grid Technik. In Ch. Henning \& E. Nestier (Eds). Konversion. Zur Aktualität eines Jahrhundertthemas [working title].

Kelly, George A. (1955). Thepsychology of personal constructs. Vol. 1 and 2. New York: Norton. 
O'Connor, Kathleen V. (1983). The structure of religion: A repertory grid approach. Doctoral dissertation, University of New South Wales, Australia.

Oser, Fritz K., \& Gmünder, Paul (1991). Religious judgement. A developmental approach (transl. Norbert Hahn). Birmingham, AL: Religious Education Press. (First German edition 1984).

Oser, Fritz \& Reich K. Helmut (1992) Entwicklung und Religiosität. In: Schmitz, E. (Ed., Religionspsychologie. Eine Bestandsaufnahme des gegenwärtigen Forschungsstandes (pp. 65-100). Göttingen: Hogrefe.

Oser, Fritz K., \& Reich, K. Helmut (1996). Psychological perspectives on religious development. World Psychology, 2(3-4), 365-396.

Overton, Willis F. (1999, August). The embodied child as agent of action. Plenary lecture at the "14th meeting of the Division Developmental Psychology" and the "7th meeting of the Division Psychology of Education" [both Divisions of the German Psychological Society], University of Fribourg, Switzerland.

Piaget, Jean (1926). La représentation du monde chez l'enfant. Paris: Presses Universitaires de France. Raeithel, Ame (1993). Auswertungsmethoden für Repertory Grids. In: Jorn W. Scheer \& Ana Carina (Eds.), Einführung in die Repertory Grid-Technik. Band 1: Grundlagen undMethoden (pp. 41-67). Bern etc.: H. Huber.

Raeithel, Ame (1995). Kooperative Modellproduktion von Professionellen und Klienten - erläutert am Beispiel des Repertory Grid. In A. Raeithel (1998), Selbstorganisation, Kooperation, Zeichenprozess. Arbeiten zu einer kulturwissenschafilichen, anwendungsbezogenen Psychologie, ed. [posthumously] C. Dahme with C. Clases, M. Hildebrand-Nilshon \& F. Seeger (pp. 209-242). Opladen, Germany: Westdeutscher Verlag.

Reich, K. Helmut (1990). The Chalcedonian Definition, an example of the difficulties and the usefulness of thinking in terms of complementarity? journal of Psychology and Theology, 18 (2), 148-157.

Reich, K. Helmut (1991). The role of complementarity reasoning in religious development. ln: F.K. Oser \& W.G. Scarlett (Guest Eds), Religious development in childhood and adolescence (pp. 77-89). Series: New Directions for Child Development, no. CD 52 (W Damon, Series Ed.). San Francisco: Jossey-Bass.

Reich, K. Helmut (1994). Can one rationally understand Christian doctrines? An empirical study. British journal of Religious Education, 16 (2), 114-126.

Reich, K. Helmut (1997). Empirical evidence for paralellisms between scientific developments from their origins to Galilei and the world view of children. Preprints des MPI für Wissenschaftsgeschichte, Berlin, no. 70.

Reich, K. Helmut (1999, September). Drei Typen von problemorientierten Interviews als Methode zur Erfassung von Religiosität. Presentation at the "Meeting Religiosität messen? of the Schweizerische Vereinigung der Religionssoziologen", Lausanne, Switzerland.

Reich, K. Helmut (2000a,July). The person-"God"-relationship: A dynamic model. Presentation at the "8th Symposium for Psychologists of Religion", Sigtuna, Sweden.

Reich, K. Helmut (2000b). The leaping lamb: lnvestigating the spirituality of children. Science and Spirit, 11 (3, July/August), 46-48.

Reich, K. Helmut (in preparation). Focusing on relationships and context. Postformal relational and contextual reasoning and its development (working title).

Reich, K. Helmut, Oser, Fritz K., \& Valentin, Peter (1994). Knowing why I now know better: Children's and youth's explanations of their world view changes journal of Research on Adolescence, 4 (1), 151-173.

Rollett, Brigitta, \& Kaminger, Gertrud (1996). Religiöse Urteilsstufen, kognitive Komplexität und Sektenneigung bei Jugendlichen. In: F. Oser \& K.H. Reich (Eds), Eingebettet ins Menschsein: Beispiel Religion. Aktuelle Studien zur Entwicklung von Religiosität (pp. 88-124). Lengerich, Germany: Pabst.

Schenker, Dominik (1996). Der Einfluss der Religiosität auf die Bewältigung existentieller Fragen bei Jugendlichen und jungen Erwachsenen. Unveröffentlichte Lizentiatsarbeit, Universität Freiburg i.Ü.

Slater, Patrick (1964). The principal components of a Repertory Grid. London: V. Andrew. 
Slater, Patrick (Ed.). (1976). The measurement of intrapersonal space by grid technique. Vol. I. Exploration of intrapersonal space. London, etc.: Wiley.

Slater, Patrick (Ed.). (1977). The measurement of intrapersonal space by grid technique. Vol. 2. Dimensions of intrapersonal space. London, etc.: Wiley.

Strauss, Anselm (1987). Qualitative analysisfor social scientists. Cambridge, UK: Cambridge University Press.

Strauss, Anselm, \& Corbin, Juliet M. (1990). Basics of qualitative research: Grounded theory procedures and techniques. Newbury Park, CA: Sage.

Todd, N. (1977). Religious belief and personal construct theory. Doctoral dissertation, Nottingham University, UK

Young, G., \& Householder, Alston S. (1938). Discussion of a set of points in terms of their mutual distances. Psychometrika, 3, 19-22. 